\title{
A Design of e-Learning Lessons to Enhance Advance Thinking Skill for Undergraduate Students
}

\author{
Sayamon Insaard
}

\begin{abstract}
This research aimed to 1) study the feasibility and appropriateness of E-learning lesson design using instructional strategy, 2) study the feasibility and appropriateness of E-learning lesson design using constructivism learning environment, 3) study the feasibility and appropriateness of using E-learning lesson for developing advance thinking skill of undergraduate students. The samples for the study were 25 experts on education technology and communication, on E-learning design, on curriculum and instruction. The research instruments consisted of 1) e-learning lessons designed on 9 instructional strategies; knowledge construction (PSPSKAPE), role play, inquiry based learning, CIPPA Model, collaborative learning, cooperative learning, project-based learning, problem based learning, case based learning. 2) e-learning lesson designed on constructivism learning environment; open learning environment (OLEs) and constructivist learning environment (CLEs). 3) Questionnaire. The data was statistically analyzed by percentage, mean $(\bar{x})$ standard deviation (S.D.)

The research findings were that 1 ) the feasibility of all types of e-learning design for developing higher-ordered thinking of undergraduate students was at the level of "most" $\quad(\bar{x}=4.69$, S.D.= 0.25), 2) the feasibility of e-learning lesson design using instructional strategy was at the level of "most" $(\bar{x}=4.68$, S.D. $=$ $0.31), 3)$ the feasibility of e-learning lesson design using constructivism learning environment was at the level of "most" $(\bar{x}=4.72$, S.D. $=0.38), 4)$ the feasibility of e-learning lesson design using instructional strategies and constructivism learning environment was at the level of "most" ( $\bar{x}=4.73$, S.D.= 0.37), 5) the feasibility of e-learning lesson design for developing higher-ordered thinking was at the level of "most" $(\bar{x}=4.68$, S.D. $=0.40), 6)$ the feasibility of e-learning lesson design for developing instructional media and higher-ordered thinking of undergraduate students was at the level of "most" $(\bar{x}=4.64$, S.D. $=0.53$ ).
\end{abstract}

Index Terms-E-learning lessons, instructional strategies, higher-ordered thinking.

\section{INTRODUCTION}

At present or the 21st century of learning age, the teachers and learners can access knowledge anytime and anywhere through the educational media called e-learning. E-learning was used as tools to support the education management of Thailand and other countries. E-learning can be used as main media or supporting media for instruction. E-learning was developed from The National Education Technology Plan,

Manuscript received October 24, 2016; revised March 24, 2017.

S. Insaard is with the Department of Educational Technology, Faculty of Education, Ramkamhaeng University, Bangkapi, Thailand (e-mail: dr.sayamon@gmail.com).
Ministry of Education, United States of America (1988) that intended to develop the 21 st century learning model of the learners by connecting new knowledge as dynamic with internet technology. The basic structure of internet technology helps more rapid for receiving and sending information. This leads to use e-Learning in terms of multimedia both two and three dimension to make instructional media more interesting and effects the learners to achieve learning objectives and effective learning.

The application of information technology for education is the policy of Thailand to get ready for information technology society and knowledge society. The country identifies the strategy of human resource development to be intelligent and have critical thinking, life-long learning, and skill of using information technology. The policy for development of educational technology is a content development that is different from the past. Information technology is an important tool for learners to access the world asset of knowledge and varieties of knowledge. The content in curriculum should be able to motivate the learners to learn eagerly, gain critical thinking and creative thinking. as e-learning lesson will be a media for higher ordered thinking skill.

The study of Science instruction condition in higher education level, it was found that electronic media was not enough for using to develop knowledge construction and critical thinking skill [1]. This was caused by the teachers are not able to design and create the e-learning lesson and e-learning courseware. The teachers or producers do not understand the content for e-learning lessons. To solve the problem is to create the e-learning lesson to enhance higher ordered thinking using constructivist learning theory and e-learning technique as a principle for making instructional media effectively.

In e-learning lesson design to enhance higher ordered thinking, the principle of constructivist is used for developing the new method of e-learning lesson design. The instructional strategies are also used in 9 strategies; the knowledge construction e-learning lesson (PSPSKAPE), Role Play e-learning lesson, Inquiry based e-learning lesson, CIPPA Model e-learning lesson, Collaborative e-learning lesson, Cooperative e-learning lesson, Project based e-learning lesson, Problem based e-learning lesson, Case based e-learning lesson, and the constructivist learning environment with 2 types; Open Learning Environment (OLEs) and Constructivist Learning Environment (CLEs) are used as the component on e-learning lesson design.

In the instructional management of any level of study, the learners are not only expected to gain knowledge, understand the content, but also gain the higher ordered thinking that 
composed of 1) Analytical thinking that concern on discrimination, classification, and grouping 2) Critical thinking that give opinion on the situation in positive and negative with information rationally, 3) Creative thinking concern new idea that is flexible and different from others, 4) Logical thinking that is able to use reason for argument or support scientifically, 5) Scientific thinking that is used to prove or find the truth. The scientific method should be supported the students to use for inspection knowledge and proved.

The instructional process for thinking has 2 ways; the use of instructional media program, programmed instruction to develop the skill and thinking process of the learners directly and the thinking process is put in the course via a content to enhance thinking skull. The learning objective of those two ways is different. The direct method of teaching to think can use the instructional media, drill or programmed instruction to develop the thinking skill of learners. The content is not important for making drill or programmed instruction, even the learning achievement. The content is considered to develop the skill and process of thinking skill. The other way is to teach thinking via the content in curriculum. The method of thinking is integrated in the learning process. The teachers will use the learning process and methodology of teaching to develop thinking skill of learners. The instruction process is not quite easy and the teachers should know the content and design the learning activity for learners to think and stimulate the learners to practice thinking while the students are learning.

From the study on factors related to critical thinking of [2], the study found that instructional media can be able to enhance critical thinking. The use of e-learning using situation and questions to stimulate learners to think, make decision, and answer in any situation by select the answer or interact with computer as desired. The teachers have to provide the vivid information and related to the real situation for learners. The learners are free to learn as desired. The e-learning lesson must be designed to enhance higher ordered thinking of learners. The research realized and intended to study the feasibility and appropriateness of new e-learning lesson to enhance higher ordered thinking of undergraduate students to gain the effective e-learning lesson.

\section{RESEARCH OBJECTIVES}

1) To study the feasibility and appropriateness of e-learning lesson design using instructional strategy.

2) To study the feasibility and appropriateness of e-learning lesson design using constructivism learning environment.

3) To study the feasibility and appropriateness of e-learning lesson for developing advance thinking skill of undergraduate students.

\section{RESEARCH METHODOLOGY}

This survey research on "A Design of e-learning Lessons to Enhance Advance Thinking Skill for Undergraduate Students" proceeded as follow:
1) A. Samples for studying the feasibility and

appropriateness of e-learning design were 25 experts who were selected from the professors and teachers who had at least 5 years experiences in e-learning design, educational technology and communication, curriculum and instruction, and gained the research of related field, derived from purposive sampling.

2) Research Instruments composed of

- e-learning lessons designed on 9 instructional strategies; knowledge construction (PSPSKAPE), role play, inquiry based learning, CIPPA Model, collaborative learning, cooperative learning, project-based learning, problem based learning, case based learning. The researcher studied the instruction process and designed e-learning lessons as the instructional strategies and presented to the experts for inspection and correction, and then implemented to the students (see Fig. 1).

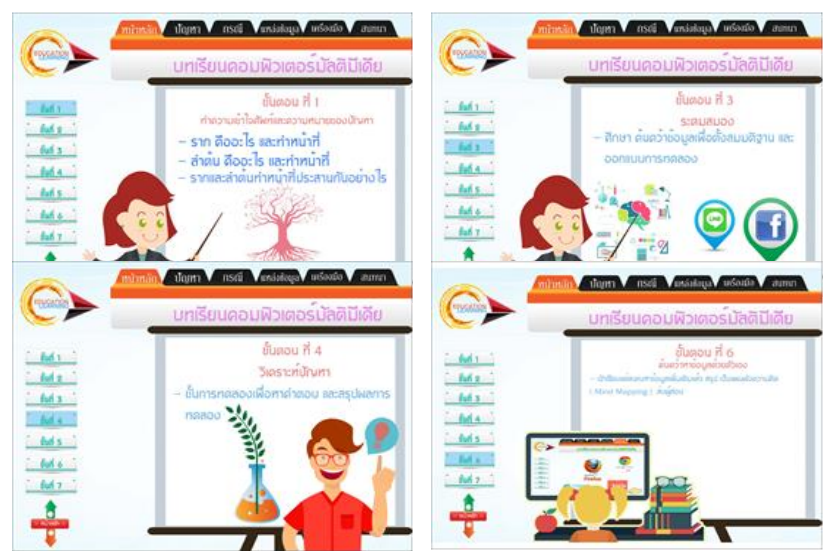

Fig. 1. Example of problem based learning approach for e-learning lesson.

- e-learning lessons design using constructivism learning environment that consisted of open learning environment (OLEs) and constructivist learning environment (CLEs). The researcher studied the component of e-learning lesson design using constructivism learning environment to design and create. The e-learning lessons were inspected by experts and be improved as the suggestion. At last, the e-learning lessons were used (see Fig. 2).
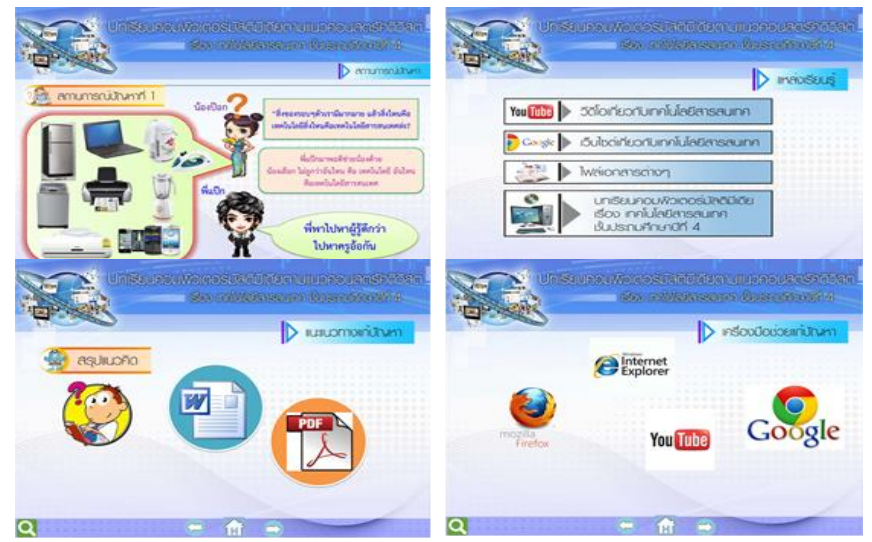

Fig. 2. Example of e-learning lessons design using constructivism learning environment (CLEs)

- Online questionnaire for studying the opinion of samples composed of 2 sections

Section 1 - the basic information of experts; position, 
educational background, work experience

Section 2 - the questions about feasibility and appropriateness of E-learning lesson design using instructional strategy, E-learning lesson design using constructivism learning environment, E-learning lesson for developing advance thinking skill of undergraduate students. The questions were classified into 5 issues; 1) The design approach in E-learning lesson design using instructional strategy, 2) The design approach in E-learning lesson design using constructivism learning environment, 3) The design approach in E-learning lesson design using instructional strategy and constructivism learning environment, 4) The design approach in E-learning lesson design for developing advance thinking skill of undergraduate students, 5) The design approach in E-learning lesson development and implementation. The questionnaire uses 5 rating scales of Likert's from most to least. The questionnaire was inspected the content validity using IOC (Index of Item Objective Congruence) by 5 experts. The IOC at $1 \geq 0.5$ was approved to use for studying.

3) The data was collected from 1-15 August 2016 via Google form at a link https://goo.gl/forms/8TA7vWE2 oSGh9asf1.

4) Data collection and data analysis - the researcher asked for cooperation from the experts to answer the questionnaire via online system about the feasibility and appropriateness of E-learning lesson for developing advance thinking skill of undergraduate students. The web link was connected to the online questionnaire. After the opinion was answered, the data was collected and analyzed.

5) Data analysis- data collected was analyzed statistically as follow:

- The basic information of experts was analyzed by frequency tally and percentage.

- The level of opinion and distribution of information was analyzed by

Mean $(\bar{x})$ and standard deviation. The criterions of opinion level were as follow:

$4.50-5.00$ referred to agree at the level of "most"

$3.50-4.49$ referred to agree at the level of "much"

$2.50-3.49$ referred to agree at the level of "average"

$1.50-2.49$ referred to agree at the level of "little"

$1.00-1.49$ referred to agree at the level of "least"

\section{RESEARCH FINDINGS}

The survey research on "A Design of E-Learning Lessons to Enhance Advance Thinking Skill for Undergraduate Students" aimed to 1) study the feasibility and appropriateness of E-learning lesson design using instructional strategy, 2) study the feasibility and appropriateness of E-learning lesson design using constructivism learning environment, 3) study the feasibility and appropriateness of using E-learning lesson for developing advance thinking skill of undergraduate students. The data was analyzed as follow:

Section 1: Basic information of experts

The basic information of 25 experts were that
TABLE I: INFORMATION ABOUT PERSONAL INFORMATION OF EXPERTS ( $\mathrm{N}=$

\begin{tabular}{lll}
\hline 25) & Number & Percentage \\
\hline 1. Sex & 13 & 52.0 \\
Male & 12 & 48.0 \\
Female & & \\
2. Academic position & 9 & 36.0 \\
Teachers (Professors) & 13 & 52.0 \\
Assistant professor & 3 & 12.0 \\
Associate professor & & \\
3. Educational Background & 3 & 12.0 \\
Master's & 22 & 88.0 \\
Ph.D. & & \\
4. Experts in & & 68.0 \\
Educational Technology & 17 & 20.0 \\
and communication & 5 & 12.0 \\
E-Learning Development & 3 & \\
Curriculum and Instruction & & 32.0 \\
5. Work Experience & 8 & 20.0 \\
5 - 10 yrs & 5 & 20.0 \\
11- 15 yrs & 5 & 28.0 \\
16-20 yrs & 7 & \\
More than 20 years & &
\end{tabular}

Table I showed the data analysis of basic information of experts. The experts were male at $52.0 \%$ and female at $48 \%$. The academic position of experts was teacher at $36 \%$, assistant professor at $52 \%$, and associate professor at $12 \%$. The educational background of experts was a master's at $12 \%$, and $\mathrm{Ph} . \mathrm{D}$ at $88 \%$. The expert in educational technology and communication was at $68 \%$, on E-Learning development at $20 \%$, and on curriculum and instruction at $12 \%$. The work experience of experts for $5-10$ years was at $32 \%, 11-15$ years at $32 \%, 16-20$ years at $20 \%$, and more than 20 years at $28 \%$.

Section 2 the data analysis of experts' opinion on the feasibility and appropriateness of E-Learning lesson design by online survey form. The questionnaire was classified into 5 level of opinion. The data was analyzed as follow:

TABLE II: THE DATA ANALYSIS OF MEAN AND STANDARD DEVIATION OF THE EXPERTS' OPINION ON THE APPROPRIATENESS OF THE E-LEARNING

\begin{tabular}{|c|c|c|c|}
\hline \multicolumn{4}{|c|}{ LESSON DESIGN } \\
\hline Description & $\bar{x}$ & S.D. & Result \\
\hline $\begin{array}{l}\text { 1. E-learning lesson design } \\
\text { using } \\
\text { instructional strategy, }\end{array}$ & 4.68 & 0.31 & most \\
\hline $\begin{array}{l}\text { 2. E-learning lesson design } \\
\text { using constructivism learning } \\
\text { environment }\end{array}$ & 4.72 & 0.38 & most \\
\hline $\begin{array}{l}\text { 3. E-learning lesson design } \\
\text { using instructional strategy }\end{array}$ & & & \\
\hline $\begin{array}{l}\text { and constructivism learning } \\
\text { environment }\end{array}$ & 4.73 & 0.37 & most \\
\hline $\begin{array}{l}\text { 4. E-learning lesson for } \\
\text { developing advance thinking } \\
\text { skill of undergraduate } \\
\text { students }\end{array}$ & 4.68 & 0.40 & most \\
\hline $\begin{array}{l}\text { 5. E-learning lesson } \\
\text { development and } \\
\text { implementation }\end{array}$ & 4.64 & 0.53 & most \\
\hline $\begin{array}{l}\text { E-learning lesson design in } \\
\text { general }\end{array}$ & 4.69 & 0.52 & most \\
\hline
\end{tabular}

From Table II the experts' opinion on feasibility of E-Learning lesson design of 5 approaches found that the appropriateness of E-Learning lesson design using instructional strategy and constructivism learning environment was at the level of "most" ( $\bar{x}=4.73$, S.D. $=0.37)$, 
the less was E-Learning lesson design using constructivism learning environment at the level of "most" $(\bar{x}=4.72$, S.D. $=$ 0.38 ), and E-Learning lesson design using instructional strategy was $\bar{x}=4.68$, and S.D. $=0.31$. The appropriateness of E-learning lesson for developing advance thinking skill of undergraduate students was at the level of "most" ( $\bar{x}=4.68$, S.D.= 0.40), and the appropriateness of E-learning lesson development and implementation was at the level of "most" $(\bar{x}=4.64$, S.D. $=0.53)$ respectively.

TABLE III: THE DATA ANALYSIS OF THE EXPERTS' OPINION ON E-LEARNING LESSON DESIGN USING INSTRUCTIONAL STRATEGY

\begin{tabular}{lccc}
\hline \multicolumn{1}{c}{ Description } & $\bar{x}$ & S.D. & Results \\
\hline $\begin{array}{l}\text { 1. PSPSKAPE E-learning } \\
\text { lesson }\end{array}$ & 4.76 & 0.44 & most \\
$\begin{array}{l}\text { 2. Role Playing E-learning } \\
\text { lesson }\end{array}$ & 4.44 & 0.65 & much \\
$\begin{array}{l}\text { 3. Inquiry E-learning lesson } \\
\text { 4. CIPPA Model E-learning } \\
\text { lesson }\end{array}$ & 4.84 & 0.37 & most \\
$\begin{array}{l}\text { 5. Collaborative E-learning } \\
\text { lesson } \\
\begin{array}{l}\text { 6. Cooperative E-learning } \\
\text { lesson }\end{array}\end{array}$ & 4.64 & 0.64 & most \\
$\begin{array}{l}\text { 7. Project Based E-learning } \\
\text { lesson }\end{array}$ & 4.68 & 0.48 & most \\
$\begin{array}{l}\text { 8. Problem Based E-learning } \\
\text { lesson }\end{array}$ & 4.68 & 0.71 & most \\
9. Case Study E-learning lesson & 4.64 & 0.57 & most \\
\hline $\begin{array}{l}\text { E-learning lesson design in } \\
\text { general }\end{array}$ & $\mathbf{4 . 6 8}$ & $\mathbf{0 . 3 1}$ & Most \\
\hline
\end{tabular}

Table III showed the data analysis of experts' opinion on the appropriateness of E-Learning lesson design using instructional strategy that was at the level of "most" ( $\bar{x}=$ 4.68, S.D. = 0.31). Considering each instructional strategy found that E-learning using problem based learning had the appropriateness at the level of "most" ( $\bar{x}=4.92$, S.D. $=0.28)$ the less was E-learning using inquiry based learning had the appropriateness at the level of "most" ( $\bar{x}=4.84$, S.D. $=0.37)$, E-learning using PSPSKAPE had the appropriateness at the level of "most" $(\bar{x}=4.76$, S.D. $=0.44)$ respectively and E-learning using role playing had the appropriateness at the level of "much" $(\bar{x}=4.44$, S.D. $=0.65)$

TABLE IV: THE DATA ANALYSIS OF EXPERTS' OPINION ON E-LEARNING LESSON DESIGN USING CONSTRUCTIVISM LEARNING ENVIRONMENT

\begin{tabular}{lccc}
\multicolumn{2}{c}{ LESSON DESIGN USING CONSTRUCTIVISM LEARNING ENVIRONMENT } \\
\hline Description & $\bar{x}$ & S.D. & Results \\
\hline $\begin{array}{l}\text { 1. Open Learning Environment } \\
\quad \begin{array}{l}\text { E-Learning lesson } \\
\text { 2. Constructivist Learning } \\
\text { Environment E-Learning } \\
\text { lesson }\end{array}\end{array}$ & 4.64 & 0.49 & most \\
\hline Total average & 4.80 & 0.41 & most \\
\hline
\end{tabular}

Table IV showed the data analysis of experts' opinion on E-Learning lesson design using constructivism learning environment. The feasibility of E-learning lesson in conclusion was at the level of "most" ( $\bar{x}=4.72$, S.D.= 0.38) and the appropriateness of E-learning using constructivist learning environment was at the level of "most" ( $\bar{x}=4.80$, S.D. $=0.41)$ and the appropriateness of E-learning using open learning environment was at the level of "most" ( $\bar{x}=4.64$, S.D. $=0.49$ )
TABLE V: THE DATA ANALYSIS OF THE EXPERTS' OPINION ON E-LEARNING LESSON DESIGN USING INSTRUCTIONAL STRATEGY AND CONSTRUCTIVISM LEARNING ENVIRONMENT

\begin{tabular}{lccc}
\multicolumn{1}{c}{ Description } & $\bar{x}$ & S.D. & Results \\
\hline $\begin{array}{l}\text { 1. The appropriateness of } \\
\text { E-learning lesson using } \\
\text { instructional strategy for design }\end{array}$ & 4.64 & 0.57 & most \\
$\begin{array}{l}\text { 2. The appropriateness of } \\
\text { E-learning lesson using } \\
\text { constructivist learning environment } \\
\text { for design }\end{array}$ & & & \\
$\begin{array}{l}\text { 3. The appropriateness of } \\
\text { E-learning lesson using } \\
\text { instructional strategy and } \\
\text { constructivist learning environment } \\
\text { for design }\end{array}$ & 4.76 & 0.44 & most \\
\multicolumn{1}{c}{ Total average } & 4.80 & 0.41 & most \\
\hline
\end{tabular}

Table V showed the data analysis of experts' opinion on E-learning lesson design using instructional strategy and constructivist learning environment. The feasibility on experts' opinion of E-learning lesson in conclusion was at the level of "most" $(\bar{x}=4.73$, S.D. $=0.37)$ and the feasibility of E-learning lesson using instructional strategy and constructivist learning environment was at the level of "most" ( $\bar{x}=4.80$, S.D. $=0.41)$ The appropriateness of E-learning lesson using instructional strategy and constructivist learning environment for design was at the level of "most" $(\bar{x}=4.76$, S.D. $=0.44)$

TABLE VI: THE DATA ANALYSIS OF THE EXPERTS' OPINION ON E-LEARNING LESSON FOR DEVELOPING ADVANCE THINKING SKILL OF UNDERGRADUATE STUDENTS

\begin{tabular}{lccl}
\hline Description & $\bar{x}$ & S.D. & Results \\
\hline 1. Critical thinking skill & 4.72 & 0.46 & most \\
2. Analytical thinking skill & 4.72 & 0.46 & Most \\
3. Creative thinking skill & 4.48 & 0.65 & Most \\
4. Logical thinking skill & 4.72 & 0.54 & Most \\
5. Scientific thinking skill & 4.76 & 0.44 & Most \\
\hline Total average & $\mathbf{4 . 6 8}$ & $\mathbf{0 . 4 0}$ & most \\
\hline
\end{tabular}

Table VI showed the data analysis of experts' opinion on E-learning lesson for developing advance thinking skill of undergraduate students. The feasibility on experts' opinion of E-learning lesson to enhance higher-ordered thinking was at the level of "most" ( $\bar{x}=4.68$, S.D. $=0.40)$. Considering in any item, the feasibility of scientific thinking skill was at the level of "most $(\bar{x}=4.76$, S.D. $=0.44)$ the less was critical thinking skill $(\bar{x}=4.72$, S.D. $=0.46)$ analytical thinking skill $(\bar{x}=4.76$, S.D. $=0.44)$ logical thinking skill $(\bar{x}=4.72$, S.D. $=$ $0.54)$ and creative thinking skill $(\bar{x}=4.48$, S.D. $=0.65)$ respectively.

TABLE VII: THE DATA ANALYSIS OF THE EXPERTS' OPINION ON E-LEARNING LESSON DEVELOPMENT AND IMPLEMENTATION

\begin{tabular}{lccc}
\hline \multicolumn{1}{c}{ Description } & $\bar{x}$ & S.D. & Results \\
\hline $\begin{array}{l}\text { 1. The appropriateness of } \\
\text { E-learning lesson design on } \\
\text { higher-ordered thinking }\end{array}$ & 4.64 & 0.57 & most \\
$\begin{array}{l}\text { 2. The ability to develop and } \\
\text { implement in a course of } \\
\text { undergraduate level }\end{array}$ & & & \\
\hline \multicolumn{1}{c}{ Total average } & 4.64 & 0.57 & most \\
\hline
\end{tabular}

Table VII showed the data analysis of experts' opinion on E-learning lesson development and implementation. The 
appropriateness of E-learning lesson design in conclusion was at the level of "most" $(\bar{x}=4.64$, S.D. $=0.53)$. The appropriateness of E-learning lesson design for development and implementation was at the level of "most" $(\bar{x}=4.64$, S.D. $=0.57)$ and the ability to develop and implement in a course of undergraduate students was at the level of "most" $(\bar{x}=4.64$, S.D. $=0.57)$

The suggestion of the experts on E-learning lesson design to enhance higher-ordered thinking of undergraduate student was as follow:

1) The feasibility and appropriateness of E-learning lesson design can enhance the higher-ordered thinking. The instructional model in conclusion is very interesting in terms of varieties to response the learning process as the learning style of learners.

2) The E-learning lesson should be flexible for learners and create self-directed learning to learners.

3) 3. The idea of using instructional strategies is very interesting.

4) The theory and methodology for designing E-learning lessons using learning activities will support to achieve learning goals. The further research should be experimented to investigate the results.

5) The content of the lessons should be considered to suit the undergraduate level. The case study for integrating the present situation in the design of E-learning lessons should be done. The content in the lesson related to the daily life experience can motivate the learners to learn and the learners will participate more in the learning activity.

6) The teachers should be expert in learning management and integrating technology in learning activity. For learners, the application of technology should be at the good level. The use of any approach will be practical.

7) The E-learning lessons that integrating instructional methodology and higher-ordered thinking, the way to access and good motivation will make benefits for learners and extend the E-learning system widely. The advantages are to use technology and enhance higher-ordered thinking to gain knowledge and top up and integrate with other science and add value for individual creatively.

8) The learning management system (LMS) through the network is a tool for designing and developing the learning process. So the time, condition of learning, and follow up the learners should be done.

9) The effective instrument should be applied to use in E-learning for learning environment such as augmented reality (AR) and virtual reality (VR). The research identified that can affect the learning goals and higher-ordered thinking.

10) The evaluation of E-learning should be promoted to study more.

\section{RESEARCH DISCUSSION}

The result of experts' opinion on E-learning lesson design to enhance higher-ordered thinking of undergraduate students can be concluded that the feasibility of E-learning lesson design was at the level of "most" and considering in any item, the opinion on E-learning lesson design using 1) instructional strategy $(\bar{x}=4.68$, S.D. $=0.31) 2)$ constructivist learning environment $(\bar{x}=4.72$, S.D. $=0.38) 3)$ instructional strategy and constructivist learning environment $(\bar{x}=4.73$, S.D.= 0.37) 4) to enhance higher-ordered thinking of undergraduate students $(\bar{x}=4.68$, S.D. $=0.40)$ and 5) to develop and implement E-learning lesson $(\bar{x}=4.64$, S.D. $=$ $0.53)$

The feasibility on experts' opinion to all of instructional strategies for E-learning lesson design was at the level of "most" ( $\bar{x}=4.68$, S.D. $=0.31)$ and E-learning lesson design using problem based learning was at the level of "most" ( $\bar{x}=$ 4.92, S.D. $=0.28)$, the less was inquiry learning $(\bar{x}=4.84$, S.D. $=0.37)$ PSPSKAPE $(\bar{x}=4.76$, S.D. $=0.44)$ respectively. This was harmonized to the research of [3] that studied the E-learning lesson using problem based learning approach and value adding to enhance the moral decision making of undergraduate students and found that the posttest score of moral decision making was higher than the pretest score at $34.33 \%$, the learning behavior of the students who studied with E-learning lesson using problem based learning was at the level of "good". And the opinion on E-learning using problem based learning was at the level of "good". The research of [4] that studied learning achievement from E-learning lesson using investigative learning approach to enhance creative thinking skill of undergraduate students found that the posttest score of the students was significantly higher than pretest score in creative problem solving, problem solving ability and learning achievement at the level of .01. In addition, [5] studied the object learning model enhancing knowledge construction and critical thinking of undergraduate students and found that the knowledge construction object learning (PSPSKAPE) composed of 6 steps; 1) present the problem, 2) study the problem, 3) find the way of problem solving, 4) construct knowledge, 5) implementation, 6) evaluation. The research found that the posttest of critical thinking skill was significantly higher than pretest at the level of .05 , and there existed a high-level elaboration at $28.57 \%$.

The E-learning lesson design using constructivist learning environment both in CLEs and OLEs and also mix with instructional strategies, the feasibility was at the level of "most". The was harmonized to [6] that studied a constructivist learning environment to enhance creative thinking of undergraduate students and found that the model composed of main components as follow: problem situation, learning resource, similar situation, intellectual tool, laboratory, creative thinking, scaffolding, advice center, efficiency of model (approved by experts), learning achievement on creative thinking, and learning achievement.

The design of E-learning to enhance higher-ordered thinking of undergraduate students, the experts' opinion on feasibility was at the level of "most". The design can enhance higher-ordered thinking in 5 approach; scientific thinking, critical thinking, analytical thinking, logical thinking, creative thinking. This was harmonized to [7] that studied critical thinking and learning achievement of the student 
teachers who studied with E-learning using case based learning. The research found the analytical thinking of average and poor students was significantly higher than pretest at the level of .05 .

For the design of E-learning lesson to develop and implement in the class, the feasibility on experts' opinion was at the level of "most". This study was harmonized to the study of [8] that mentioned interactive E-learning lesson in instructional design development (ISD) in practical and raise some example about E-learning lesson created from computer program called Raptivity that helped to gain interactive content in E-learning lesson easily. The inventor did not need to have high skill in computer technology or expert as a programmer. The template of E-learning lesson was provided for making and compatible with theory of Bloom (Bloom's Taxonomy), motivation theory of Keller (Keller's ARCS Model), learning theory of Gagne (Gagne's Nine Events) or any experiential learning theory.

From the result of the experts' opinion on E-learning lesson design to enhance higher ordered thinking of undergraduate students, the researcher suggested to support a development of new dimension of E-learning lesson design, including e-books, intelligent media system to make lesson easily as the steps of instructional strategies and components of learning environment. The teachers who are not expert in instructional media production, the teachers should be able to develop the creative E-learning lesson. With the consistency of E-learning lesson using instructional strategies, the higher ordered thinking still happened to the students effectively.

\section{SUGGESTION}

\section{A. Suggestion from the Research Findings}

1) The design of E-learning lesson to enhance higher ordered thinking of undergraduate students is to integrate the instructional strategies, higher ordered thinking and E-learning to motivate the students or learners to learn will extend the use of E-learning widely and benefit to the learners.

2) The application of technology to enhance higher ordered thinking should be applied and integrated in other science.

3) The lesson designer, instructors, learners should be expert in learning management and integrate the technology, and the learners are also good at using technology.

\section{B. Suggestion for Further Study}

1) The E-learning lesson using instructional strategies and constructivist learning environment should be created for developing higher ordered thinking of the learners.

2) The design of E-learning lesson to enhance higher ordered thinking for undergraduate students should be topped up for intelligent media production using instructional strategies and component of learning environment.

\section{REFERENCES}

[1] P. Panichphun et al., A Study of Instructional Process in Science and Mathematics in Undergraduate Level, TH: Mahidol Univ. 1998, pp. 24-28.

[2] W. Yimyuan, "Meta-analysis of factors related to creative thinking," M.Ed. thesis, Dept. Educational Technology., Chulalongkorn Univ., Bangkok, Thailand, 2004.

[3] N. Hapa, "E-learning lesson using problem based learning approach and value adding to enhance the moral decision making of undergraduate students majoring in educational technology," Veridian E-Journal, vol. 8, no. 2, pp. 1749-1765, August 2015.

[4] C. Pinthanasuwan, "A study of learning achievement from investigative e-learning lesson to enhance creative thinking skill of undergraduate teacher students," M.Ed. thesis, Dept. Educational Technology., Silpakorn Univ., Nakhon Pathom, Thailand, 2013.

[5] S. Insaard, "A development of object learning model enhancing knowledge construction and critical thinking of undergraduate students of suranaree university of technolgy," Ph.D. dissertation, Dept. Educational Technology., Chulalongkorn Univ., Bangkok, Thailand, 2010.

[6] J. Chamart, "A development of constructivist learning environment to enhance creative thinking of undergraduate students," Ph.D dissertation, Dept. Educational Technology., Khon kaen Univ., Khon kaen, Thailand, 2009.

[7] W. Kaewprasert, "A study of critical thinking and learning achievement of the student teachers who studied with e-learning using case based learning," Veridian E-Journal, vol. 7, no. 2, pp. 947-961, August 2014.

[8] S. Thanawasathian and C. Sakjirapaphong, A Design of Interactive e-Learning Lesson, Bangkok: Digitent Co. Ltd, 2006, ch. 1.

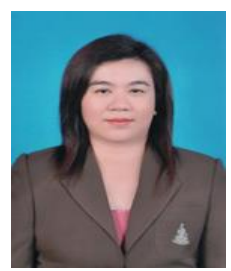

Sayamon Insaard was born on February 14, 1971, in Bangkok, Thailand. She got the doctor of philosophy in education program (educational technology and communications), Chulalongkorn University, Thailand.

Asst. Prof. Sayamon Insaard Ph.D., Department of Educational Technology, Faculty of Education, Ramkhamhaeng University. 